\section{War and reconstruction in northern Mozambique}

Tilman Brück

$\mathrm{T}$ his article discusses some of the economic effects of war in northern Mozambique. It indicates how the historical and structural features of the economy of northern Mozambique restricted post-war reconstruction and postwar poverty alleviation. These features include the dominance of only a few cash crops for export, the absence of much rural trading, poor communication infrastructure, and weak political and state institutions. The specific nature of the internal war further weakened the state through the collapse of tax revenue and export earnings and the massive growth of debt and aid, of which little reached rural northern Mozambique. The chapter also summarizes key aspects of the geography, climate, markets, and social institutions of northern Mozambique, which define the potential production opportunities for peasant households. For example, the degree of land abundance in rural areas is illustrated and markets are shown to have been restricted or destroyed entirely by the war in rural northern Mozambique. Finally, the article suggests how post-war reconstruction could have been more effective in achieving faster post-war poverty alleviation in northern Mozambique.

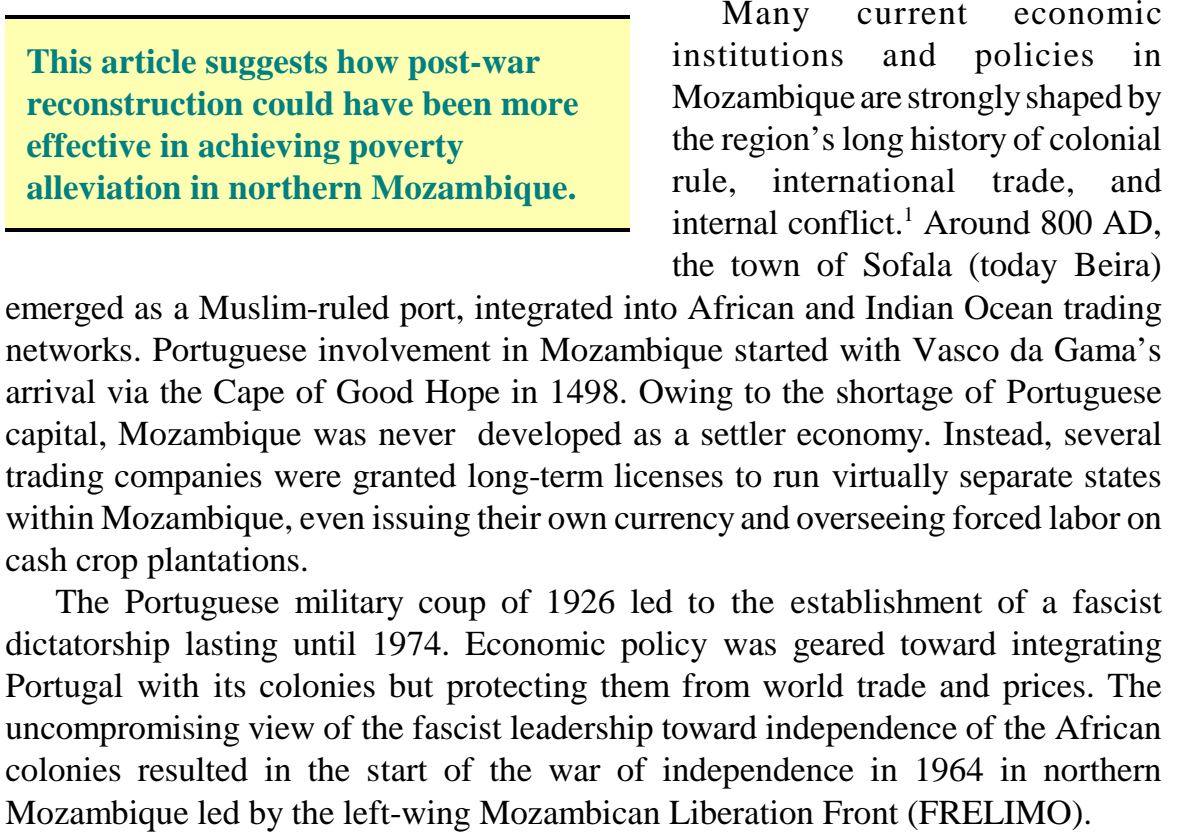

The independence war came to an unexpected end with the military coup in Portugal in April 1974. In September of that year the Lusaka Accord arranged the transfer of political power from Lisbon to Maputo within nine months but failed to resolve many economic or legal aspects of the changeover. This resulted in an illprepared FRELIMO leadership and an economically and politically uncertain future for independent Mozambique.

As South Africa's president from 1978, P.W. Botha introduced a policy of destabilization aimed at weakening left-leaning, black- ruled frontline states, including Mozambique. Rhodesia helped to set up the rebel group RENAMO as a mercenary movement launching strikes against Mozambican and pro-Zimbabwean targets. The Zimbabwean independence in 1979 ended the costly Mozambican participation in the embargo of Rhodesia and induced South Africa to take over from Rhodesia its support for RENAMO. Afonso Dhlakama assumed the leadership of RENAMO in 1980 and continues to hold it in late 2004. The start of the Mozambican internal war is disputed but it is safe to assume that by 1980 at the latest it had become a serious security threat throughout the country.

Despite FRELIMO's earlier decision to convert itself to a communist party, Mozambique's application for entry into the Comecon trading bloc was rejected in 1981. This induced the Mozambican government in 1982 to apply for membership in the International Monetary Fund (IMF), which it joined in 1984. Mozambique was thus the first country ever to undergo both a transition from socialism and a set of structural adjustment programs.

The first IMF structural adjustment program was introduced in Mozambique in 1987. Subsequently almost all state-owned enterprises (including state farms and financial companies) were privatized in one of the most comprehensive privatization programs ever to take place in Africa. In 1990, peace negotiations between the Mozambican government and RENAMO convened in Rome and led to a partial cease-fire in the Zimbabwean-Mozambican railway corridors. In the following two years southern Africa experienced a severe drought, threatening over three million Mozambicans with starvation.

FRELIMO and RENAMO signed a cease-fire agreement in October 1992 in Rome, which led to UN peacekeeping forces (ONUMOZ) arriving in Mozambique from March $1993 .^{2}$ The first free parliamentary and presidential elections were held under UN supervision in October 1994. FRELIMO won by a narrow majority in parliament with 44 percent of the vote versus RENAMO's 38 percent. The incumbent president Joaquim Chissano of the FRELIMO party was elected with 53 percent of the vote while the RENAMO candidate Afonso Dhlakama polled 34 percent. The ONUMOZ mandate ended in December 1994.

Since these elections, Mozambique has been a parliamentary democracy with the president's appointing provincial and district governors, except in the largest 13 municipalities. For these, free local elections were held in 1998. Because RENAMO 
boycotted the elections, FRELIMO and independent candidates won the vote. In December 1999, the second free parliamentary and presidential elections were held. FRELIMO maintained its majority in parliament with 133 seats versus 117 seats held by the RENAMO-led opposition coalition. President Chissano was re-elected with 52 percent of the vote while the RENAMO candidate Dhlakama polled 48 percent. RENAMO did not accept the result of the election in its post- election speeches and political violence has since increased across the country. Large-scale floods especially in southern Mozambique caused significant damage in early 2000.

These historical developments

Historical Impacts on the Mozambican Economy

1. Portuguese colonialism left a legacy of weak economic institutions with monopolistic cash crop traders, highly contested rural political institutions, and forced agricultural labor.

2. The absence of a human capital base at independence and the haste of the independence process led to a serious weakening of central political institutions.

3. The range of international opponents of the FRELIMo regime successfully destabilized the national economy. affect the analysis presented in this article in several ways. First, Portuguese colonialism left a legacy of weak economic institutions with monopolistic cash crop traders, highly contested rural political institutions, and forced agricultural labor up to independence. Second, the absence of a human capital base at independence and the haste of the independence process led to a serious weakening of central political institutions (these were often either misunderstood or unable to influence directly rural economic developments). Third, a range of international opponents of the FRELIMO regime successfully destabilized the national economy in that there was no integration of different regions within the country and an unbalanced integration of the national economy in international trading systems. The integration instead occurred within the landlocked industrial economies of the south, the rural economies in the north, and the settler economies of central Mozambique.

\section{The nature of the war}

The post-independence war in Mozambique had external and internal causes. ${ }^{3}$ The former, reviewed above, further include the end of apartheid and the Cold War and the international community's desire to assist the victims of the 1991-92 drought. The latter include a failure of FRELIMO to understand rural issues and to persuade large sections of the rural population and their traditional leadership of FRELIMO's case for change. For example, large-scale village resettlement and collective village programs failed as they did not address the underlying causes of underdevelopment and as villagers were not in control of these programs. FRELIMO thus placed itself on many occasions in the position of the hated colonial authorities, creating a climate that fostered implicit or even outright support for RENAMO.

Yet RENAMO did not possess a viable alternative strategy for rural development. Instead, its aim was the destruction of government infrastructure and thus the demonstration of FRELIMO's lack of power. By the end of the war RENAMO did not control a single Mozambican city or town as it was both unable to sustain a major attack and uninterested in territorial gain. Such an aim of destruction required little direct fighting and little central coordination, making the rebels unpredictable, a characteristic also of their behavior in the post-war demobilization period. Given its original war aim, RENAMO's war effort was supremely effective though at a massive cost to the whole country.

With the relative lack of easily extractable natural assets in Mozambique (compared to say Angola or Liberia) the end of war was endogenously determined. ${ }^{4}$ Neither the government nor RENAMO were able to sustain the

fighting financially and the drought of 1991-93 finally forced a settlement. Diplomatically, the war was ended as a draw but politically the FRELIMO government had to compromise little of its initial stance. The fact that politically Mozambique was a very different country at the end of the war owed less to RENAMO's political philosophy or bargaining strength and more to the ability of the FRELIMO party to re-invent itself over the decades, most recently as a largely probusiness party, while being led by a virtually unchanged group of politicians.

From an economic point of view, the key characteristics of the war were thus a high level of uncertainty and a large-scale destruction of assets and infrastructure. These were caused by RENAMO’s war strategy, an absence of clearly defined battle lines, a high risk of attack for rural households and rural infrastructure (most towns were reasonably protected by the government army), and a long time horizon. These characteristics of the war strongly shape its expected effects on numerous variables. For example, the constant risk of attack in rural areas meant farmers had to look out for or flee from attacks, thus strongly reducing their effective labor supply. These points emphasize the general finding that the nature of conflict has a strong impact on the nature of the economic effects of war. ${ }^{5}$

Geography, markets, and institutions in northern Mozambique

This section reviews the external constraints facing poor, war-affected peasant 
households in northern Mozambique, which in many ways is a distinct economy from the center and the south of the country. Northern Mozambique is in fact considered the most agriculturally productive part of the country and has long been an area for cotton cultivation. The soil conditions of coastal districts such as Moma, Angoche, or Nacala are more suited to cassava, rice, cashew, and coconut, while intermediate districts such as Monapo, Meconta, or Montepuez grow predominantly maize, cassava, sorghum, cotton, and some cashew. The interior districts of Nampula province such as Ribaué or Lalaua also have favorable conditions for maize and tobacco and grow some cotton but no cashew.

The rail infrastructure was badly
damaged by the war, with the national
stock of operational locomotives
declining from 222 in 1982 to 158 in
1989.

The main transport corridor (the so-called Nacala corridor) connects the port of Nacala with the provincial capital Nampula, then with Niassa province and finally Malawi by road and potentially by train. The rail infrastructure was badly damaged by the war with the national stock of operational locomotives declining from 222 in 1982 to 158 in $1989 .{ }^{6}$ A main road also connects the town of Nampula to Pemba, the capital of Cabo Delgado province. There is little overland traffic or trade with southern Tanzania due to poor infrastructure, the low population density in the border region, and the large river Rovuma dividing the countries. The road connecting Nampula with southern Mozambique was poorly maintained for most of the post-war period.

Nampula city, with about 206,000 inhabitants in 1994, is the third largest town in the country and is the main urban center of northern Mozambique. Overall, Nampula, Cabo Delgado, and Niassa provinces had about 5.17 million inhabitants in 1995, representing 33 percent of Mozambique’s total population. Portuguese is the only official language of Mozambique but only 6 percent of the population speak Portuguese fluently while in Nampula province Macua is the dominant local language. ${ }^{7}$

The climatic and topographical conditions of northern Mozambique are suitable for rain-fed agriculture, though conditions are variable both across space and time. The interior districts generally have higher rainfall and better soil conditions compared to the coastal areas. Environmental factors in the north differ significantly from those in the south of the country, suggesting potentially large gains from domestic agricultural trade.

These observations imply that agricultural conditions are generally favorable for rain-fed agriculture in post-war northern Mozambique. National and international trade in agricultural commodities is feasible in northern Mozambique but has been inhibited by high transport costs in the past.

Northern Mozambique has a population density of 19 inhabitants per square kilometer. Partially as a result of this low population density, peasant households do not irrigate their land or use animal-drawn or mechanized ploughs. The use of inputs is also very low, except for some pesticide use in cotton growing.

Land can most easily be devalued through the planting of land mines. This was done frequently and widely in Mozambique. On the one hand, if the exact distribution of the mines is not certain, the planting of only a few mines will increase insecurity and uncertainty significantly and will devalue large areas of land. Returnees in particular may be unaware of mined areas, and children and livestock are at a high risk of accidentally stepping on mines if they leave safe areas or passages. This suggests that the clear demarcation of possibly mined areas and public information campaigns, especially among refugees and in schools, can yield large dividends by reducing mine-induced death and disability.

On the other hand, most land mines do not kill; in particular they tend not to kill local, adult residents. This applies even more to those who did not leave their areas during the war, as they may know which land remains safe. Mine victims are thus mainly post-war returnees, children playing in unknown areas, and people attempting de-mining. This pattern suggests that a key issue in the analysis of the effects of land mines is the distribution of their costs (as well as of their perceived benefits when produced and planted).

Furthermore, in a land abundant country, reducing the supply of land is not a significant economic constraint in the immediate post-war period. It has been estimated that post-war agricultural production in the absence of land mines would have increased by only 4 percent in Mozambique versus 88 percent to 200 percent in Afghanistan and Cambodia where arable land is generally considered to be less abundant. ${ }^{8}$ This view was also supported by interviews in Maputo with mine-clearing staff working in Mozambique in 1995 who thought that public information and mine mapping exercises were more useful and cost effective than large-scale mine-clearing programs.

Given the relatively low warvulnerability of land, households increased their dependency on landbased strategies during the war and for much of the post-war reconstruction effort. At the same
Households increased their dependency on land-based strategies during the war and for much of the post-war reconstruction effort. time, there are no landless

households in rural areas and there are only very few large, village-based landowners. In Cabo Delgado and Nampula provinces there are very few other large so-called private (i.e., business-like) landowners, except for a few sisal plantations that derived from colonial land concessions. It is worth noting that there are thus no land-lease, sharecropping, or other principal-agent relations as are common in Asia and other, more densely populated African countries. 
This high degree of land dependence coupled with an apparent land abundance but also with an unequal distribution of land can be explained with reference to imperfect land allocation mechanisms. The key institutions governing land access are the traditional, colonial, political, and post-independence political authorities. These authorities emerged and were created at different times in history but continue to coexist and represent different levels of traditional society and state authorities.

One reason for the internal war in Mozambique was the dispute over the role of these authorities in rural life. This policy issue continues to generate significant debate in the post-war period. The role of traditional authorities generally depends very much on the standing of the individuals, on the war experience of the community, and on the issues under consideration. Low-level authorities, for example, can resolve land disputes if they concern intra-village disputes; but a state authority may better resolve the relatively rare disputes between peasant households and private farmers.

Given these physical and cultural environments, peasant households typically either acquire land through inheritance via maternal or paternal families (the Macua are a matrilineal society) or are allocated new land by traditional authorities. Such new land can often be genuinely new (virgin) land or it may be land previously abandoned (which implies a degree of disowning exceeding that of fallow land) by other households.

Peasant households in Mozambique could not claim full statutory property rights on land in the mid-1990's, as the government formally owned all land. The Mozambican government was reviewing land tenure legislation throughout this period, finally drafting an innovative land law that today grants the right to secure land tenure to entire communities but not to individual peasant households. However, large-scale, private landowners were always able to obtain de facto full property rights. A high degree of corruption through large-scale land grabbing has been alleged since the end of the war. Yet the provinces most affected appear to be those with the lowest population density like Niassa or those with a longer history of plantation farming, such as for sugar in the south.

An informal survey of households found that in Monapo district both men and women can inherit land and that they are allocated land without payment primarily by local or traditional authorities. ${ }^{9}$ Two thirds of households in Monapo occupied land previously owned by other households while one third of households used virgin land. In Meconta, land is allocated mainly to men through traditional authorities and no payment is made for land there either. ${ }^{10}$ In that district, 20 percent of all households farm land that has previously been farmed, while 60 percent of households occupy previously virgin land.

These observations suggest that many peasant households face a large supply of land or even land abundance. Formal property rights at the local level in northern Mozambique are minimal. The war and traditional society were the major influences on peasant household land institutions and allocation decisions. Rural households can satisfy a large share of their demand for land in most cases. In some important cases, however, households are constrained in their land choice, for example through custom for female-headed households. Consequently, land abundance is a householdlevel concept, not a macro-level concept, in post-war northern Mozambique. Such concept is akin to the concept of commodity and household-specific market failure and has strong implications for the design and interpretation of post-war reconstruction policies.

The war reduced the mean annual population growth rate of Mozambique from 2.5 percent in $1970-80$ to 1.7 percent in $1980-97 .{ }^{11}$ However, these values mask highly variable mortality and fertility rates, which are both particularly high in the north. In Nampula province, for example, the total fertility rate in 1997 was 6.3. During the war, mortality rates were even more variable. While the average mortality rates fell over time to about 1.6 percent in the late 1980's, civilians living in war zones had mortality rates of up to 14 percent per year. ${ }^{12}$

Other health indicators for 1997 were low, too, with 96 percent of the population in northern Mozambique having no access to piped water, 78 percent having no access to health services, and 39 percent of all children under 3 years of age being moderately or severely underweight. The life expectancy at birth in the north was 41 years in 1997. Interestingly, the gender structure of the northern population was quite balanced (with 50.7 percent of all residents being female in 1997), probably due to the equal effect of the terrorizing war on the civilian population and due to the high share of very young people who were no longer directly affected by the war.

The adult literacy rate in 1996 was 28 percent, a figure that was directly war-related as the rebels specifically targeted schools and teachers in rural areas. In the period 1983-92, 58 percent of all primary schools were destroyed through fighting or had to close due to the high level of insecurity. ${ }^{13}$
Health Indicators (1997)

\section{- 96percent of the population in} northern Mozambique had no access to piped water.

- 78 percent had no access to health services.

- 39 percent of all children under 3 were moderately or severely underweight.

- The lift expectancy at birth was 41 years.

The rebels specifically targeted schools and teachers in rural areas. From 1983-1992, 58 percent of all primary schools were destroyed by the fighting or had to close because of it. 
In addition to these quantitative and qualitative constraints on labor, rural labor markets in northern Mozambique were very fragmented, weak, and disrupted by the war. There were few agricultural or non-agricultural employment opportunities and few migrant workers, unlike in southern Mozambique. For example, only 11 percent of all rural households occasionally or regularly employed agricultural labor. ${ }^{14}$ The Macua culture, the main ethnic group in northern Mozambique, has strong customs regulating the hiring-in of casual labor and the mutual exchange of group labor. Although this may not reduce the level of labor market transactions, it adds an additional layer of meaning to the hiring-in or hiring-out of household labor.

An important feature of the war and immediate post-war labor markets was the extreme degree of displacement induced by the war of destabilization. Approximately half of all Mozambican households were

\section{Approximately half of Mozambican} households were local, national, or international refugees by the end of the war.

\section{local, national, or international}

refugees by the end of the war. This indicates that most other household coping strategies failed given the severity of the war and that a large number of households must have been extremely close to the survival threshold to invoke such drastic coping strategies. Furthermore, the scale of migration to government-held areas during the war indicated some trust in the government and its allied NGO's by a large majority of the population of rural areas. This is in stark contrast to the extreme atrocities committed in the rural areas throughout the war, which for example led to 88 percent of children resident in war zones witnessing physical abuse and/or torture. $^{15}$

\begin{abstract}
By the mid-1990s it could be said that land and labor markets did not exist in rural northern Mozambique.
\end{abstract} to the lack of large-scale labor
markets, and had experienced traumatic, life and livelihood threatening displacement until the very end of the war. In fact, these indicators may even suggest that both land and labor markets did not, in fact, exist in rural northern Mozambique as would be expected in more developed or more densely populated areas. These factors can be expected to have had strong implications for the type of agricultural activities households were interested in or capable of pursuing. rural Mozambican labor force in the mid-1990's had extremely poor health and education, was very dependent on own-farm income due
These indicators suggest that the These war-affected tangible and
Some kinds of agricultural production were particularly vulnerable to war damage. For example, the number of cattle declined from over 1.3 million in 1982 to 0.25 million in 1992.

Agricultural production and the rural infrastructure were severely damaged and destroyed during the war. Facilities in smaller localities or with a higher degree of immobility or visibility endured proportionately more war damage, making some forms of rural production virtually impossible. For example, the number of cattle in Mozambique declined from over 1.3 million in 1982 to 0.25 million in 1992 as rebels looted and killed livestock and rural veterinary services and livestock markets collapsed. ${ }^{16}$

In addition to threats to production, marketing structures were also severely damaged. The number of private shops, which often were the only rural providers of key goods such as tools, salt, and soap, and frequently acted as purchasers of agricultural crops as well, fell by 39 percent while the number of Agricom posts, outlets of the agricultural marketing board, fell by 74 percent in the period 1982-88. ${ }^{17}$

Transport costs of export crops increased due to the cost of protection for the convoys traveling from rural areas to the ports and due to the inability of the state to maintain rural roads in times of already large fiscal deficits and of high levels of insecurity on these roads. Nevertheless in the post-war period, crop markets appear to have become increasingly integrated at the national level, although this did not appear to prevent large, isolated rural areas from being poorly integrated into the post-war distribution and pricing of food crops. This is also confirmed by the large variability shown in particular by food crop prices versus consumer prices as recorded by rural household surveys.

The marketing of tools was very difficult in the post-war period leading to regular shortages of high quality, hand-held tools. This was accentuated by the lack of blacksmiths in rural areas, a phenomenon that may be related to negative cultural perceptions of blacksmiths.

The war hence involved the destruction of assets and institutions in a deliberate and significant way. intangible institutions ${ }^{18}$ then led to strongly rising transaction costs.
The war involved the deliberate destruction of assets and institutions. The destruction in turn led to sharp rises in transaction costs.
Many peasant households thus

ceased to produce large quantities of cash crops or to sell food crops. For example, Mozambican cashew output accounted for 43 percent of world cashew production in 1969-71 but only for 5 percent in 1989-91. ${ }^{19}$ Cotton production in Cabo Delgado and Nampula provinces declined from 83,000 metric tons in 1973 to 19,000 metric tons in $1988 .^{20}$ 
The war-induced isolation of households in rural Mozambique implied that most households were nearly self-sufficient in most commodities and that commerce was mainly limited to low weight, low volume, non-perishable, and essential items such as salt, soap, dried fish, batteries, and T-shirts. ${ }^{21}$ The high covariance of output fluctuations reduced opportunities for profitable inter-household exchange (trade across space) within a given area. In fact, the share of purchased food in total food consumption in northern Mozambique was only 22 percent in 1995.

It was also not profitable for households to hold significant stocks of crops beyond those required for expected own consumption in the hungry season. The storage costs and losses would have outweighed the expected benefit of such trade across time. There were hence few regular, annual agricultural output markets within homogenous agricultural areas.

Overall, the effects of war were both direct and indirect and the cumulative effect on the capacity for growth in the whole economy was debilitating. Rural peasant households were forced by the war into an extreme form of subsistence and even autarky.

\section{Other rural institutions}

A key sector in many rural development programs is the rural finance sector, which includes savings associations, rural development banks, and moneylenders. However, these institutions exist in virtually no rural areas in northern Mozambique, a result of the effects of the war and the related extreme poverty. The only sources of credit at that time were informal consumption loans among farmers, often in times of ill health to attend hospital.

Further rural institutions include the three cotton joint venture companies (JVC's) - Lomaco, Sodan, and Samo - which were set up in 1990 by the government and by British and Portuguese enterprises. ${ }^{22}$ In a set-up not dissimilar to the colonial period, each JVC was allocated an exclusive area of influence and thus monopsony rights for cotton at prices set each season by the government in line with world cotton prices. These spatial monopsonies were intended to help overcome the large costs and uncertainties associated with purchasing cotton in a low-density and insecure area. In return, JVC's had to provide inputs, extension advice, and other services to farmers. In addition, the government annually set a minimum cotton price to protect smallholder interests against the JVC's and from changing world prices.

In 1994-95, about 81,000 peasant households participated in this scheme with these JVC's. ${ }^{23}$ In practice, these companies never carried out many of the functions envisaged for the JVC's, in part because the costs of operating in post-war rural areas had been overestimated ex ante. Pesticides were allocated to most cotton growers but little extension advice and no fertilizers or other cash or food crop seeds were provided.

Finally, unless located near a main inter-provincial transport corridor, almost no rural farm household would have had access to electricity, telecommunications, postal services, or regular public transport. Some areas were able to receive a state radio station so that owning a radio was a source of information and key status symbol in post-war rural areas.

\section{Macro-economic trends in the post-war period}

At the end of the war in 1992, Mozambique was very poor even by African standards. There was hope that the economy would realize a peace dividend, that is, an increase in output and an improvement in the fiscal position as a result of the end of the war. Yet by late 1995, only small progress had been made and expectations of future growth were much reduced.

One objective of this article is to explain why the aggregate supply response in rural areas in northern Mozambique (and indeed national GDP growth) was so muted in the early post-war period. The main hypothesis is that the effects of the war had been underestimated in 1992 and that they had a long-lasting negative effect on agricultural growth (both of food and cash crops) throughout most of the 1990s. ${ }^{24}$

In 1992, Mozambique was very poor had dropped to less than $1 / 5$ of the mean level of all sub-Saharan Africa countries.

adjustment. During the next two years, growh
even by African standards. Output

As a result of de-colonization and the war, Mozambican output in 1987 had dropped to less than onefifth of the mean level of all subSaharan African countries. Output in the period 1987-89 rose by 5 percent due to the increased levels of foreign aid and structural adjustment. During the next two years, growth was below 2 percent as aid flows diminished, the war intensifies, and a drought adversely affected southern Africa. In 1992, the economy shrunk by 1.4 percent while the population growth was still high despite the war. These pressures led to the peace agreement thus permitting a resumption of high inflows of humanitarian aid.

The partial economic recovery of the early 1990's can be explained by the end of capital destruction and the high levels of uncertainty caused by the war, a credible peace agreement and peace process, the high inflow of resources with the factual two-year UN occupation of the country, the return of large numbers of displaced people, related increases in the total land cultivated, favorable weather conditions, continued high levels of aid, continually improved macroeconomic management, increased competition in many markets, and increasing inflows of foreign direct investment. 
Persistent constraints in the early 1990's included the low levels of physical infrastructure, the fragility of civil and state infrastructures, the subsequent high levels of transaction costs as well as the geographic, economic, and social isolation of many peasant households, their low agricultural productivity, the poor domestic and regional integration of the economy, the continued high levels of foreign debt, the high budget deficit, the balance of payments disequilibrium, the correspondingly overvalued exchange rate, high real interest rates, and still low levels of government policy-making capacity.

The start of the IMF stabilization program raised the consumer price index of Maputo dramatically in 1987 and led to continued urban inflation until after the departure of ONUMOZ. With normalization of the security situation and of the macroeconomic policy management, urban inflation fell for the first time to below 20 percent in 1996. Maputo prices are strongly determined by southern Mozambican food prices and by the Metical-Rand exchange rate, as South Africa is (southern) Mozambique's main trading partner. However, in the mid-1990's prices were mainly determined by market forces, not by government controls, as was the case for 70 percent of legal market transactions in $1986 .^{25}$

There is no reliable data in Mozambique on rural-urban relative prices and thus on the internal terms of trade. Estimates suggest that increased international trade in cash crops led to reduced marketing margins for cash crops and to increased marketing margins for food crops in the period 1991-96, therefore encouraging the production of food crops by smallholders. ${ }^{26}$ This analysis suggests that the lifting of domestic price controls or their non-enforcement, the increasingly liberalized exchange rate mechanism, and the liberalization of foreign trade sent proper market signals to producers, especially from the mid-1990s onwards. ${ }^{27}$ Leakages of food aid may have had a depressing effect on some agricultural producer prices at the height of the 1991-92 famine but this effect is unlikely to have been as significant in $1995 .^{28}$ The net effects of the war on the price mechanism per se and on rural-urban prices is thus likely to have occurred through significantly raised transaction costs.

Foreign direct investment (FDI) increased dramatically with the end of the war. Total approved annual FDI in all sectors except minerals and commerce was about US\$ 30 million during 1985-93. This low value must have been due, at least partly, to the war. In comparison, in the immediate post-war period, mid-1993 to end-1994, US\$ 443 million of FDI were approved by the Mozambican government under new investment legislation. Furthermore, US\$ 9.6 billion worth of FDI was under consideration or being committed in 1999, mainly in very large projects in heavy industries, natural resource extraction, and commerce. ${ }^{29}$

The key macro indicators were therefore only slowly improving by the end of the war. Consequently, the output response to the end of war (i.e., the production peace dividend) was quite slow in the first post-war years. Food production per capita increased by almost 9 percent per year in the period 1993-96 but this was from a historically low base so that by 1996 the pre-war level of food production per capita had not yet been attained. The productivity of exports for example, expressed in exports per capita, was even more damaged by 1992 relative to its pre-war level and had not yet reached the pre-war level by 1998. Structural adjustment policies also helped to raise export earnings in the late 1980's but failed to affect significantly the supply response of farm households. The dual policy challenge of the post-war period was therefore to identify and remove the constraints to rural development and export performance in order to achieve a long-term, peacetime economic equilibrium.

Such a weak export performance had significant implications for the external equilibrium. Western aid and trade liberalization in the 1980's as well as the ONUMOZ mandate in the early 1990's increased imports by 140 percent in the period 1985-94 thus raising the trade deficit from 10 percent to 61 percent of GDP in the same period. With the departure of ONUMOZ the trade deficit fell significantly but it remained above wartime levels throughout the post-war period. This led the government and donors to support both large-scale foreign direct investment and the adoption of cash crops such as cotton. Yet both policies remain contentious in Mozambique. Even if such policy aim was accepted, there is no broad consensus as to how cash crop exports can be increased most effectively and which consequences this may have for rural development and poverty alleviation.

In addition to the low level of realized output there has also been a strong inequality in distribution of growth across sectors and space. In 1996 agriculture contributed 28 percent to total GDP while manufacturing and construction accounted for 21 percent and services for 51 percent of GDP. ${ }^{30}$ The large size of the tertiary sector is in part caused by the large inflow of foreign aid and the related presence of many donors in Maputo.

In fact, the economic development of Maputo still drives a large part of the economic growth of Mozambique, with the city of Maputo accounting for 34 percent of total GDP in 1996-98 but only for 6 percent of the population in 1999. The north of the country accounts for 21 percent of total GDP and 33 percent of total population with Nampula province (which contains the city of Nampula) being the largest province in that region. In the central region it is worth noting that Beira, the capital of Sofala, is the second largest city in the country and the origin of the Beira corridor linking Harare and Lusaka with their nearest port. Mozambique is thus characterized by large regional and rural-urban inequalities that mask even deeper rural and 
northern poverty than the already low GDP per capita figures indicate.

The scope for raising productive government spending in response to the end of war (i.e., the government finance peace dividend) was quite small in the first postwar years. Total government spending as a share of GDP actually fell from 52 percent in 1990 to 34 percent in 1996, partly as a result of a fall in military expenditure after the ONUMOZ departure. However, this fall was limited and postwar spending on health and education stayed below its peak of 5 percent of GDP. The dominant cause of the falling expenditure and continually low social spending was the low government revenue which resulted in a mean fiscal deficit of 26 percent of GDP in the war-period 1987-92 and of 21 percent of GDP in the post-war period 1993-97.

The Mozambican government has two main sources to help fund this dramatic fiscal deficit, namely external debt and foreign aid. External debt reached its historical high value of 406 percent of GDP in the last year of the war, which in part accounts for the end of the war in that year. Even though the value of the external debt stock started to fall in the post-war period, it still accounted for 262 percent of GDP in 1998.

The other important source of finance for the government and indeed the whole Mozambican economy is foreign aid. Aid from the Organization for Economic Cooperation and Development (OECD) countries started to increase strongly from 1987 and peaked at 118 percent of GDP in 1992. With the receding humanitarian disaster and the departure of ONUMOZ aid then fell rapidly in the post-war period and "only" accounted for 39 percent of GDP in 1997. Nevertheless, foreign aid was still worth more than twice as much as government revenues in 1997, thus continuing to exert a strong "Dutch disease" effect on the competitiveness of Mozambican exports. $^{31}$

Like output, foreign aid was not distributed evenly across Mozambique or across sectors. The United Nations Development Program (UNDP) calculated that aid per capita in the period 1995-97 was spent disproportionately in Maputo city and province. Furthermore, only 9 percent of all foreign aid spent in 1995-97 was allocated to agricultural projects, with 19 percent being committed to humanitarian and food aid, 24 percent to economic management and administration, and the remainder to a range of smaller sectoral programs. ${ }^{32}$

This evidence suggests that the peace dividend in Mozambique had not started to materialize by 1995 , that the capacity of the state to initiate development projects was very weak, and that aid resources were available to help lift the supply constraint but that these resources were not geared toward northern Mozambique or agricultural projects. The average peasant households in northern Mozambique were hence virtually unconnected with post-war government or donor economic activity or indeed post-war output growth.

\section{Conclusions}

The discussion suggests that there are several general prerequisites for successful post-war reconstruction policies appropriate for northern Mozambique. These include recognizing the many negative war legacies in the economy, the role of public goods in overcoming them, and the need for decentralizing reconstruction policy. Government and donors can assist post-war peasant households by providing public goods to enhance market participation and investment opportunities. Post-war public policy must recognize the importance of local and individual differences in the experience of war and aim to decentralize its interventions given that different villages or districts may face different constraints to expanding production and trade. Other policy options include re-capitalizing war-affected households and enhancing human capital.

However, there should be no choice between investing in physical capital and investing in human capital. The broad destruction of war at the household and market levels requires an integrated approach to rebuilding human, physical, and institutional assets. It may be administratively easier to organize selective large-scale programs. Yet the key war legacies will only be overcome with integrated rural development programs.

Households under conditions of war maintained their food security to an incredible degree by retreating into food subsistence production. In the post-war period, they faced increasing incentives to return to market-based agricultural and especially tradeable food crop activities. Policy makers can thus encourage waraffected households to consolidate their post-war welfare gains by strengthening rural food crop markets and opening international markets for northern Mozambican food crops. Alternatively, they can try to improve the incentives for adopting cash cops and expanding off-farm activities. Given the persisting war legacy, the consequent need to restore basic market and social institutions, and the weak capacity of the state in rural northern Mozambique, the former policy option appears to offer higher returns for some time to come.

The organization of a widespread rural education network should not take priority from an agricultural production point of view. Enhancing the household coping strategies perfected in a situation of near market autarky during the war appears to be a relatively low-cost and yet effective agricultural development, poverty alleviation, and above all food security strategy for the early post-war period in northern Mozambique.

In summary, post-war reconstruction policies should assist market reconstruction and support the expansion of household production, as this is not possible for many 
(C) www.epsjournal.org.uk - Vol. 1, No. 1 (2006)

households without outside support. Policies should help to rebuild public goods as well as household-specific physical and human capital and take into consideration the diverse effects of war across locations.

\section{Notes}

Tilman Brück is at the International Economics department of the Deutsche Wirtschaftsforschungsinstitut (DIW), Berlin.

1. Hall and Young, 1997; MacQueen, 1997; Newitt, 1995.

2. Barnes, 1998; Synge, 1997; Vines, 1998.

3. Finnegan, 1992; Geffrey, 1991; Hume, 1994; and Vines, 1996.

4. Brück, 2000.

5. Stewart, 2001.

6. Brück, 2000.

7. UNDP, 1998.

8. Andersson, 1995; Human Rights Watch Arms Project, 1994.

\section{UNHCR, 1997.}

10. UNHCR, 1997.

11. UNDP, 1999.

12. Cliff, 1988.

13. Ministério da Educação, 1994.

14. UNDP, 1999.

15. Boothby, 1991.

16. Ministério da Agricultura, 1994.
17. World Bank, 1990.

18. North, 1990.

19. Cramer, 1999; and UNDP, 1998.

20. Fok, 1995.

21. Brück, 2000.

22. Pitcher, 1996; Isaacman , 1996; and Tschirley and Weber, 1994.

23. Strasberg, 1997.

24. Brück, 2000.

25. Andersson, 1998.

26. Arndt, Jensen and Tarp, 2000.

27. Tschirley, 1999.

28. Tschirley, 1999.

29. Brück, 2000; Muchine, 1999.

30. UNDP, 1999.

31. Brück, 2000.

32. UNDP, 1998.

\section{References}

Andersson, P.A.. and B.B. Sjöö. 1998. Inflation during the Transition to Market in Mozambique. Cambridge, MA and Goteborg.

Andersson, N., C.P. da Sousa, and S. Peredes. 1995. "Social Cost of Land Mines in Countries: Afganistan, Bosnia, Cambodia, and Mozambique.” British Medical Journal 311(7007):718-721.

Arndt, C., H.T. Jensen, and F. Tarp. 2000. “Stabilization and Structural Adjustment in Mozambique: An Appraisal.” Journal of International Development 12:299- 
323.

Barnes, S. 1998. “Peacekeeping in Mozambique,” pp. 159-177in O. Furley and R. May, eds., Peacekeeping in Africa (Aldershot, UK: Ashgate).

Boothby, N., P. Uptom, and A. Sultan. 1991. Children of Mozambique: The Cost of Survival. Durham, NC: Duke University Press.

Brück, T. 2000. “The Economics of Civil War in Mozambique,” pp. 191-215 in J. Brauer and K. Hartley, eds., The Economics of Regional Security: NATO, the Mediterranean, and South Africa (Amsterdam: Harwood).

Brück, T., E.V.K. FitzGerald, and A. Grisby. 2000. "Enhancing the Private Sector Contribution to Post-War Recovery in Poor Countries.” QEH Working Paper Series. Oxford, Queen Elizabeth House. Available online at: http://www.tilmanbrueck.de

Cliff, J. and A.R. Noormahomed. 1988. "Health as a Target: South Africa's Destabilization of Mozambique.” Social Science and Medicine 27(7):717-722.

Cramer, C. 1999. "Can Africa Industrialize by Processing Primary Commodities? The Case of Mozambican Cashew Nuts.” World Development 27(7):1247-1266.

Finnegan, W. 1992. A Complicated War: The Harrowing of Mozambique. Berkeley, CA: University of California Press.

Fok, M. 1995. The Cotton Sub-Sector in Mozambique: Institutional Diversity, Performance and Prospects for Improvement. Maputo, World Bank.

Geffrey, C., 1991. A Causa das Armas. Porto: Edições Afrontamento.

Hall, M. and T. Young. 1997. Confronting Leviathan: Mozambique since Independence. London: Hurst \& Co.

Human Rights Watch Arms Project. 1994. Landmines in Mozambique. New York: Human Rights Watch/Africa.

Hume, C. R. 1994. Ending Mozambique's War. Washington, DC: United States Institute of Peace Press.

Isaacman, A. 1996. Cotton is the Mother of Poverty: Peasants, Work and Rural Struggle in Colonial Mozambique, 1938-1961. Portsmouth: Heinemann.

MacQueen, N. 1997. The Decolonization of Portuguese Africa. London: Longman.

Ministério da Educação. 1994. "Impacto da Guerra na Educação 1983-1992.” Maputo.

Ministério da Agricultura. 1994. Unpublished data. Maputo.

Newitt, M. 1995. A History of Mozambique. London: Hurst \& Co.

North, D.C. 1990. Institutions, Institutional Change and Economic Performance. Cambridge: Cambridge University Press.

Pitcher, M.A. 1996 "Conflict and Cooperation: Gendered Roles and Responsibilities within Cotton Households in Northern Mozambique.” African Studies Review 39(3):81-112.

Pitcher, M.A. 1996. "Recreating Colonialism or Reconstructing the State? Privatisation and Politics in Mozambique.” Journal of Southern African Studies
22(1):49-74.

Stewart, F. and E.V.K. FitzGerald, eds. 2001. War and Underdevelopment. Oxford: Oxford University Press.

Strasberg, P.J. 1997. "Smallholder Cash-Cropping, Food-Cropping and Food Security in Northern Mozambique.” Department of Agricultural Economics. East Lansing: Michigan State University.

Synge, R. 1997. “Mozambique’s Peace Process: UN Peacekeeping in Action, 1992 94.” Washington, D.C., United States Institute of Peace Press.

Tschirley, D.L. and M.T. Weber. 1994. "Food Security Strategies Under Extremely Adverse Conditions: The Determinants of Household Income and Consumption in Rural Mozambique.” World Development 22(2) 159-173.

Tschirley, D.L., C. Donovan, and M.T. Weber. 1996. "Food Aid and Food Markets: Lessons from Mozambique.” Food Policy 21(2):189-209.

Tschirley, D.L. and A.P. Santos. 1999. "The Effects of Maize Trade with Malawi on Price Levels in Mozambique: Implications for Trade and Development Policy.” East Lansing, MI: Department of Agricultural Economics, Michigan State University.

UNDP. 1998. Mozambique Development Cooperation Report 1995-1997. Maputo.

UNDP. 1998. Mozambique National Human Development Report 1998. Maputo.

UNDP. 1999. Mozambique National Human Development Report 1999. Maputo.

UNHCR and UNDP. 1997. District Development Profiles: Monapo District, Nampula Province. Maputo.

Vines, A. 1998. “Disarmament in Mozambique.” Journal of Southern Africa Studies 24(1):191-206.

Vines, A. 1996. Renamo: From Terrorism to Democracy in Mozambique? London, James Currey.

World Bank. 1990. Mozambique: Restoring Rural Production and Trade. Washington, DC: World Bank. 